\title{
The Benefit of Waste Bank for Poor Families in Sicanang Belawan, Medan, North Sumatra
}

\author{
Mujahiddin, ${ }^{1}$ Ananda Mahardika ${ }^{2}$ \\ ${ }^{1}$ Social Welfare Department, Faculty of Social Science and Politics (FISIP), UMSU, Medan, Indonesia \\ ${ }^{2}$ State Administration Department, Faculty of Social Science and Politics (FISIP), UMSU, Medan, Indonesia
}

\begin{abstract}
Waste bank-based management concept is needed to be able to recycle the waste produced by each individual in the household. The presence of SJM (Simpan Jadi Mas)Waste Bank on sub village V of Sicanang, Belawan, Medan City, is managed to change the paradigm of people who formerly saw the waste as a dirty, disgusted object and had no meaning, but now it has turned into something which is valuable and can be saved. Based on that, this study will see how the use of waste savings for poor families in Belawan Sicanang village of Medan. In this study, it will be described some theoretical descriptions related to the concept, the advantages of waste banks and waste savings as well as the poor families. The research method used a qualitative approach with five poor families as the subjects who become the customers of SJM Waste Bank. The data collection technique used is in-depth interviews with data analysis technique used a qualitative approach of interactive model as proposed by Miles and Huberman. The results of this study found that there are two advantages resulting from the waste savings they are economic advantages and social advantages. The economic advantages are marked by extra income of poor families used to meet the food needs, to meet the cost of children's meals and to help the rental cost of boat. Meanwhile the advantages of waste savings socially is there are a change in behavior that is marked by a change of behavior in sorting the inorganic waste by types and the increasing participation in preserving the environment. Besides that, there is individual skills improvement on poor families which is marked by the ability to recycle the inorganic waste into creation things.
\end{abstract}

Keywords: waste savings; benefit; poor families; Belawan

\section{INTRODUCTION}

Waste production from year to year has increased. One of several factors that caused to increase the waste production is the growth of population. The higher the number of the population is, the greater the amount of the communities consumption that all will end up as waste. Augus and Muja (2016) describe waste can be interpreted as the rest of the material goods that are not wanted by the people, either in individual or home scale. That is why people or communities become producers of the waste itself. In Medan City as reported by Central Statistics Agency (BPS) during 2008 to 2012 it is seen that there had been improvement in waste production. In 2008 to 2009 there was an increase for 33.85 tons of waste production. While from 2009 to 2010 the increase was 677.89 tons. However, between 2010 to 2011there was a reduction in waste production for 22.6556 tons. Meanwhile in 2011 to 2012 there was again an increase for waste production to 270.3306 tons.

Likewise, in an effort to describe the problems resulting from the waste, at least something can be done by changing the way of the public's view about waste in order not to be afraid, hate and disgust any longer,. This is in accordance with Article 4 of Regulation No. 18 Year 2008 about Waste Management. It is explained that waste management aims to improve public health and environmental quality as well as to use the waste as a power source. Waste as a power source can be understood as an effort to be able to utilize the waste back into one useful material,

Muja (2016) explains in many studies' results that there have been found many advantages that can be generated from waste as a power source which can be processed and reused. For example the organic waste generated by households can be used as compost. In fact there is one study result suggests that organic waste is eligible as a raw material for anti-mosquito product. Meanwhile the inorganic waste is usually recycled to be accessories especially waste from plastics that can be chopped back and then melted into plastic pellets to be used as raw material in the manufacture of plastic goods. In the research branch of social sciences, the research usually has trash theme that always associated with community participation in waste management or about the level of public health caused by poor waste management. This can be seen from a study conducted by Ibrahim Candra from University Tanjungpura, Pontianak with the title: People's Participation in Household Waste Management (A Case Study in Siantan village of North Pontianak). The results show that the level of participation in waste management is determined by the level of ability, willingness and opportunity, which is 
divided into six indicators; (1) attitude towards the environment and programs, (2) motivation to get involved in the program, (3) the level of experience in waste management before the programs, (6) waste program management (Candra, 2012). Candra then concludes that there are two factors that have a relationship with the level of participation, the level of willingness and level of ability. Meanwhile the level of opportunity has no relationship with the level participation. From above it can be concluded that psychological aspect is more decisive in waste management. A positive attitude and a strong motivation will lead to the desire of citizens to participate, as well as the level of knowledge has an influence on the citizen involvement in waste management programs (Chandra, 2012).

The presence of waste Bank Simpan Jadi Mas(SJM) in sub village V of Sicanang, Medan Belawan, Medan City, managed to change the paradigm of the people who formerly saw waste as dirty, disgusted and has no meaning object, has now tu rned into useful and valuable thing. This is because the waste-especially inorganic types such as plastics, cans, etc- can be used as savings with promising valuable money. That is why it is now almost every morning, especially when the sea water of Belawan is tidal many people flock out to gather the plastic waste brought in by the tide.The amount of public interest to participate in the waste management business through waste bank program - with waste savings and loans-can be seen from the large number of customers registered at SJM Waste Bank. Until September 2016 there are 60 people with a total savings of inorganic waste per day by $\pm 30 \mathrm{Kg}$. On that reason this study will analyze how waste savings is benefit for poor families who become the customers of SimpanJadi Mas (SJM) Waste Bank in Sicanang village of Medan Belawan.

\section{METHOD OF RESEARCH}

This research was conducted with a case study approach to five poor families who become the customers of SJM Waste Bank. This approach was chosen in order to reveal deeply about how the waste savings is benefit to poor families in Sicanang village of Belawan. The sampling technique or informants in this study used a purposive sampling model. These five families are considered to represent the overall customers at the SJM Waste Bank. The collected data through interviews and observations were then analyzed in qualitative approach with interactive model as proposed by Miles and Huberman that consists of three main things; data reduction, data presentation and conclusion or verification. The whole process is linked with before, during and after the data collection (Idrus, 2009).

\subsection{Waste Bank}

Waste Bank is one of several concepts or waste management model. Suwerda (2012) divides the waste management which is carried out by people today into four types, (1) Household waste management with traditional systems. (2) Household waste management by gathering-loading-throwing system. (3) Waste management with independent and productive system and (4) the waste management by waste savings in waste bank. This waste management model through waste bank is a form of waste management business by applying the principle of the 3-R (Reduce, Reuse, Recycle). In waste banks, the system implemented is a system to manage waste and to accommodate, then to sort and to distribute the waste to other waste treatment facility or to those who need it. Here the value of goods that have become waste can be increased which previously useless into useful products. Besides, shelters and treatment efforts by distributing to other waste treatment facilities or to those who need them also help to reduce the intensity of the dump to Waste Place (TPS) or Final Waste Place (TPA).

Seeing from the understanding, Utami (2013) explains that waste bank can be regarded as a collectively dry waste management system which encourages people to participate actively in it. This system will accommodate, sort, and distribute economic value waste on the market so that people get the economic benefit from waste saving. So all activities within the waste bank system means from and for people. The waste deposited by the customer should be sorted. This rule encourages people to separate and classify the waste. For example, based on the type of material; plastic, paper, glass and metal. Thus, the waste bank will create a new culture so that the people would like to sort the waste. Thus, the waste bank system can be used as a tool for social engineering. So there is a better order or a waste management system in the society (Utami, 2013).

\subsection{Poor Families}

According to Regulation No. 52 year 2009 about Population Improvement and Family Development, in Chapter 1 Article 1, verse 6 describes that the family is the smallest unit of society consists of husband, wife, or husband and wife and son or father and child (widower), or mother and child (widow). In general, family can be defined as the smallest organizational unit in society that consists of head of family - either men or women-and some people who get together and stay in a place under one roof in dependent on each other. William J. Goode as quoted by Soelaeman (2011) states that a family function include sexual arrangements, reproduction, 
socialization, maintenance, determination of the child in society, social and economic needs satisfaction and social control.

But for most families all those function cannot be performed fully maximum. Poverty becomes one factor that affects the family cannot run the functions in maximum. Maintenance function such as education, the function of social and economic needs satisfaction is a difficult function to be realized in maximum by this poor family. This is due to the low ability of the poor families to accumulate their social power base. According to John Friedman in Suyanto (2013) the social power base is; The First, productive capital on assets, such as residential land, equipment and health. The Second is the financial resources such as proper income and credit. The third, social and political organization that can be used to achieve the whole interests, the fourth is social networks to obtain proper employment, goods, knowledge and skills. And the fifth is useful information for life.

The lack of ability to accumulate this social base makes many individuals, families trapped in the poverty circle. This is what Robert Chamber (1987, in Suyanto 2013) states as the core of the poverty problem. According to him, deprivation trap or poverty trap consists of five elements: (1) the poverty itself, (2) the physical weakness, (3) the isolation or social level, (4) vulnerability and (5) powerlessness. These five elements are often intertwined each other so that they are poverty traps that are the most dangerous and deadly for the life chances of poor people or families. What was revealed by Chamber about the derivation trap got a serious attention by Stamboel. According to Stambol there are four major obstacles that caused Indonesian poor people trapped in the poverty. The obstacles include structural obstacle, human capital obstacle, institutional obstacle and socio-cultural obstacle (Stamboel, 2012: 28).

\subsection{The Benefit of Waste Bank and Waste Saving}

\section{RESULTS AND DISCUSSION}

The presence of waste banks in several cities in Indonesia is hoped to be able to provide the significant advantages for the people. Suwerda (2012) notes that there are four advantages can be expected from the presence of the waste bank as waste management model. Those waste banks then are expected to benefit for first the health environment, second for social and economic of the people, third for educational aspects and fourth, for the government.

For the health environment, waste bank presence is expected to create a clean and healthy environment, reducing the waste burning habit and piled the waste. Meanwhile for socio-economic aspects, the waste bank is expected to add the family income from waste savings, and also can establish a good social inter-society relationship. For educational aspect, the presence of waste bank is expected to change the people habits in managing the waste they produced. By the presence of waste bank, it is expected that the people are able to sort out the waste from the house before saving it to the waste bank. Another advantage produced from a savings bank and waste saving is that it can be a driving mechanism of change in the people's lives. This is revealed from the research results conducted by Syafrini (2013) where at one of the study points concludes that wives who have not worked, after becoming a customer of the waste bank they have jobs opportunities to produce plastic waste into valuable objects which the results of it can help to increase the economic needs of the family.

For waste savings Syafrini (2013) explains that the balance shown in the saving account of the customers is adjusted to the weight of the per-item collected waste which then calculated at a predetermined price. This means that the more waste is taken, the more money to save, despite the fact that once they save the waste, the money is not so much, only about Rp.3000, - up to Rp.35.000, - for once saving. However, according to the customers with this profit, they are more eager to collect the household waste and sometimes the waste seen on the streets or in the office, is taken home with the hope it can be saved.

\subsection{Waste Saving for Poor Families}

The presence of waste banks in several cities in Indonesia should be able to provide significant advantages for the society. Suwerda (2012) notes there are four advantages that can be expected from the presence of the waste bank as a waste management model. The waste banks are expected to be advantageous for first, environment health, second for social and economic of the people, third for educational aspects and fourth, for the government. For the environment health, the presence of the waste bank will be able to create a clean and healthy environment, to reduce the habit of burning and piling waste. Meanwhile for socio-economic aspect, the waste bank is expected to add the family income from waste saving, and can also establish good social relationships among the society. For educational aspect, the presence of waste bank is expected to change the habits of people in managing the waste produced. With the presence of waste bank, it is expected to be able to sort out the waste from the house before saving it to the bank.

Another advantage from a waste bank and waste saving is that it can be a mechanism of change trigger in people's lives. This is revealed from the results of a research conducted by Syafrini (2013) where in one of research points concludes that the housewives who do not work, after becoming customers of the waste bank they have job opportunities by manufacturing plastic waste into valuable objects which the result can help to 
increase the economic needs of the family. For waste savings Syafrini (2013) explains that the balance shown in the saving account of the customers is adjusted to the weight of the per-item collected waste which then calculated at a predetermined price. This means that the more waste is taken, the more money to save, despite the fact that once they save the waste, the money is not so much, only about Rp.3000, - up to Rp.35.000, - for once saving. However, according to the customers with this profit, they are more eager to collect the household waste and sometimes the waste seen on the streets or in the office, is taken home with the hope it can be saved.

The same thing also happened to SJM waste bank's customers in Sicanang village of Medan Belawan. For them, the presence of waste saving models offered by SJM waste bank brings many advantages for their families, both economically and socially. . The economic advantages are marked by extra income of poor families used to meet the food needs, to meet the cost of children's meals and to help the rental cost of boat. Meanwhile the benefit of waste savings socially is there is a change in behavior that is marked by a change of behavior in sorting the inorganic waste by types and the increasing participation in preserving the environment. By those advantages, many poor families in Sicanang village, particularly in the $\mathrm{V}$ sub village of Block B PulauCanang, participated by becoming the waste bank customers. This increasing participation can be seen from the number of customers who previously only 35 people, now becomes 60 people. This increasing number makes the amount of waste saving deposit to the waste bank increased. Based on the record of SJM waste bank the amount of inorganic waste customers each day is 25 - $30 \mathrm{~kg}$ per day in which previously was only $15-20$ $\mathrm{Kg}$ per day. The whole waste deposited to SJM waste bank then sorted by bank officials that will be sold to collectors with the waste will be recycled to be used as accessories and objects other creations.

\subsection{Benefit in Economy}

The presence of community participation in waste bank based waste management business is certainly influenced by changes in the value of waste from the worthless, dirty and smelly into an economically valuable. Because of the waste bank, waste that had been discarded can now be saved and converted into units of waste value economically. The change of waste value then brings the impact of poor families in sub village V Block B of Sicanang Belawan village. The most felt thing by the people is the increasing amount of income from waste saving. The increasing income helps them much to meet the food needs of the family, to cover school fees and to help in covering daily operational costs of the family.

Amna for example, as a bank customer she says the sale of waste and her waste saving has been use for the purposes of household expenditures and children's education expenses including transportation to school. As the head of single-person who has long left her husband, the result of the waste saving is much helps Amna, especially in the current financial situation which is difficult. Usually when the time of finance is in difficult situation to finance school fees and pocket money of her children, Amna has to use her waste saving money. In addition, if her waste saving has reached Rp.30.000, - or Rp. 50.000, - Amna will use the money to buy the kitchen needs such as; rice and cooking oil. Not only for children's school fees and household needs, sometimes Anna's waste saving also used for the purposes of renting a boat for Rp. 15.000, - per day. Because of the income from the sea is not be able to cover the cost of renting the boat. So she decided to go into the sea to catch fish and look for plastic waste. The result, besides getting the fish for sale is Amnah also gets plastic waste which sometimes amounts to one or two kilos. The waste is then kept first for two or three days. She does this so that the nominal amount of waste saving may be more.

What Amnah has done is similar to what other families have done who become the customers of SJM waste bank. The waste saving they have in common is always used for the purposes of school fees, to fulfill the household expenditures and operational costs for sea purposes such as renting boat fee or the cost to repair the boat. (For more details see Table 1)

Table 1The Benefit of Waste Savings Economically

\begin{tabular}{|c|c|c|}
\hline Customer Name & $\begin{array}{l}\text { Amount of Money For One- } \\
\text { Time Waste Saving }\end{array}$ & Benefit in Economy \\
\hline Amnah & Rp. 15.000 - Rp. 20.000,- & $\begin{array}{ll}- & \text { Children's meals } \\
\text { - } & \text { Buying household needs such as; rice and } \\
& \text { frying oil } \\
\text { - } & \text { Renting boat to sea }\end{array}$ \\
\hline Supriadi & Rp. 12.000 - Rp. 20.000 & $\begin{array}{ll}\text { - } & \text { Children's meals } \\
\text { - } & \text { Buying household needs such as; rice, fish, } \\
\text { and frying oil } \\
\text { - } & \text { Repairing boat }\end{array}$ \\
\hline Aisiah & Rp. 15.000 - Rp 20.000 & $\begin{array}{l}\text { - } \quad \text { Children's meals } \\
\text { - } \quad \begin{array}{l}\text { Buying household needs such as; LPG Gas, } \\
\text { rice, and frying oil }\end{array}\end{array}$ \\
\hline
\end{tabular}


The Benefit of Waste Bank for Poor Families inSicanangBelawan,

\begin{tabular}{|c|c|c|}
\hline Sri Ramadani & Rp. 10.000 - 12.000,- & $\begin{array}{ll}\text { - } & \text { Children's stationary needs } \\
\text { - } & \text { Children's meals }\end{array}$ \\
\hline Asna & Rp. 10.000 - 15.000,- & $\begin{array}{ll}\text { - } & \text { Children's meals } \\
\text { - } & \text { Buying household needs such as; rice, } \\
\text { frying oil and LPG Gas. } & \\
\text { - } & \text { Renting boat }\end{array}$ \\
\hline
\end{tabular}

The table above shows how big the advantages of saving waste economy are for the poor in the sub village V Block B of Sicanang Belawan village, Medan particularly in this case meeting the daily needs of households that include buying the staple household needs and children's pocket money also help the renting cost and repairing boat. Moreover, the waste saving has always been used by poor families when their financial situation is in difficult circumstance. Although the nominal value for once saving is only Rp.10.000,- up to Rp. 20.000 ,- but if it is accumulated, sometimes it can be Rp.50.000, - up to Rp.120.000,-. The amount of money is exactly what they always use fully when the financial conditions are in difficult circumstances.

Figure.1

The benefit of waste bank for poor family

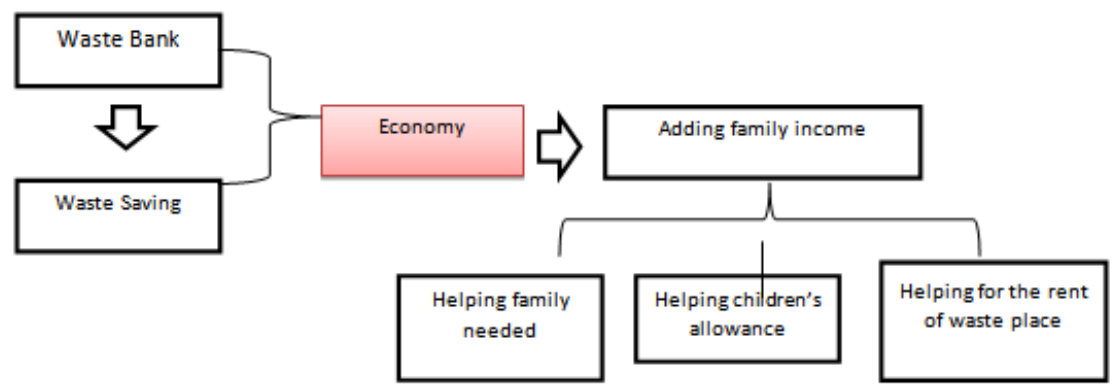

The big amount of waste saving economically makes the poor families in sub village V Block B of Sicanang Belawan village are no longer ashamed and disgusted to pick and collect plastic waste especially water mineral bottles and shampoo bottles. Even when the tide sea of Belawan comes, many people get ready to collect plastic waste brought in by the sea water. The waste collection is then cleaned and sorted by type then bring them to the waste bank and save the money.

\subsection{Social Benefit}

Not only economically, the advantage from waste savings felt the people is in socially. This can be seen from the change behavior both individuals and groups in waste management. If first the household waste dumped in the waste, sewer or at sea, now the household waste has started to be sorted by type. Besides, the waste around home yards has also begun to be collected, especially the waste taken from the tidal waters of Belawan. Waste that has been collected and sorted is then taken to the bank to save it.

According to Supriya, there has been a change behavior in managing the waste since he became the waste bank customers. For him the specified requirement by the bank is the waste should be sorted before save it, this makes him learn to do the sorting of inorganic waste from home. The result is Supriya now provides specific sacks to each type of waste such as; plastic bottles, glass bottles and the rubber waste.

Besides Supriya, the change of behavior in waste management also felt by Amnah. According to her, since the waste bank with its waste savings program, she and many other customers began to consider waste as a valuable thing. So each time finding a plastic waste either sellable or for material creation, Amnah always picks and collects them in a provided container. In this case Amnah also explains, inorganic waste generated by households or waste generated from tides of Belawan she still sorts them by the type. This makes her easier to find out which types of waste are already eligible to save to the bank in one week. Amnah managed to collect two to three kilos of waste with a plastic type.

The public's behavior change especially becoming waste bank customers brings a positive effect on the cleanliness of the environment in the sub village V Block B of Sicanang Belawan village. Because there is no plastic waste anymore strewn on the street, in the home yards or in waste bins. The other side of a positive effect on the environment is the society especially the customers of a SJM Waste Bank who are no longer throw any waste into the sea or their home's ditches. So this can reduce the amount intensity of the plastic waste in Belawan Sea. Moreover, the customers like Amna and Supriya always encompass a plastic waste in the ocean every time they go fishing. Other advantage from the presence of waste bank socially is the increasing of the poor families' skills and knowledge about waste management process into useful products and worthy life. At this stage, the SJM Waste Bank provides special training for the poor who have become the waste bank customers. The provided skill training is in the form of inorganic waste management technique which is difficult 
to decompose in order to become useful items. Normally inorganic waste is in the form of residual plastic waste packaging products processed into shopping bags, wallets, footwear drinks and plastic flowers are attractive. For the rest of newsprint processed into baskets and potted ornamental flowers. Meanwhile the rest of the unused cloth from fabrics is processed into broses, chain key, dolls and other trinkets jewelry.

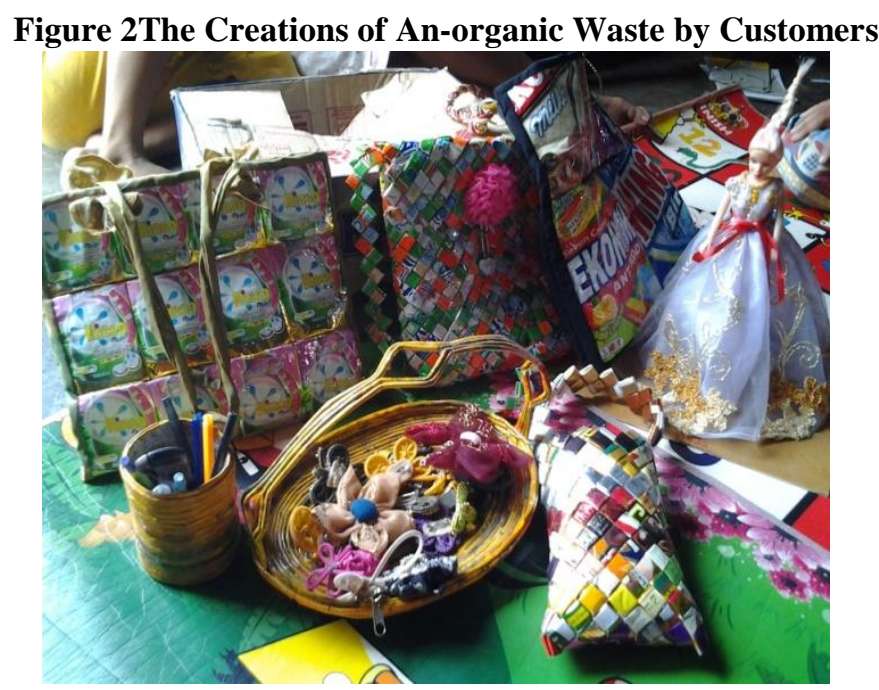

The produced inorganic waste results are then marketed individually to anyone who wants to buy them. Sri Ramadani said the price offered to buyers is various depending on the difficulty in making them. Once they sold a bag of a plastic material for Rp.25.000,-. While Asna sold Barbie doll from her creations for Rp.30.000,-. Furthermore, Asna said that to get good plastics that can be processed into bags and shopping purses, they have to look for them specifically. Because the plastic materials that will be used as raw materials processed to make handbags and purses cannot be found in the waste bank. This is because second hand plastic does not have a sale value in waste bank.

Likewise, Sri and Asna said that they have not been able to determine the price of their creations crafts at the right price corresponding to each product. During this time the waste processed goods are sold at uncertain price. If the waste processed goods are bought by the civil servants then will they raise the price, but if the buyers are ordinary people then they will sell them at an affordable price. The low ability to market their creation products from recycled inorganic waste makes the waste management business of this sector has not given great advantages to the customers. The advantages are just perceived only the skill improvement in waste management and additional income out of waste savings.

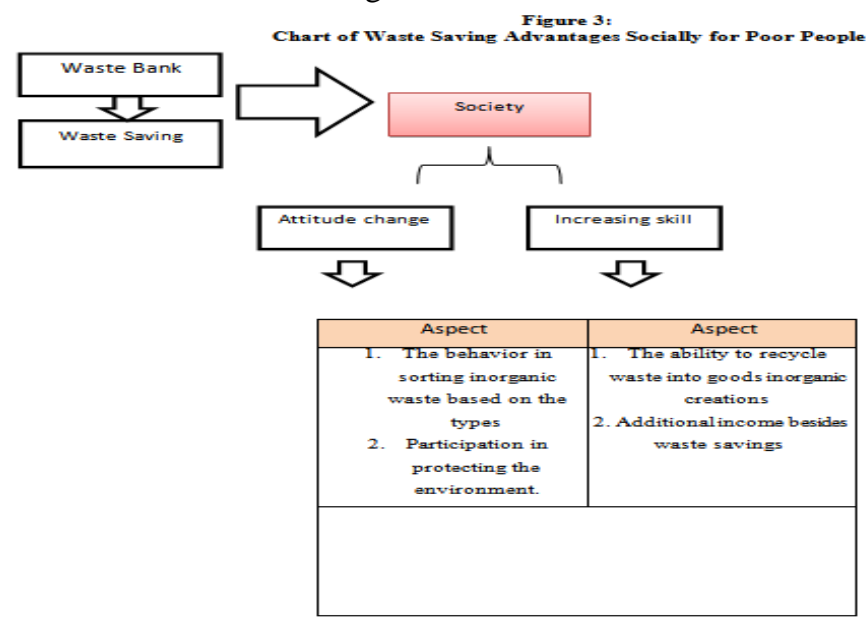

\section{CONCLUSION}

Based on the discussion results above, it shows that the presence of SJM Waste Bank with waste saving program provides some advantages to the poor families in the sub village V Block B of Sicanang Belawan village. There are at least two advantages felt by the poor from the waste savings; 1 . The advantages economically which are marked by the family's additional income from the waste saving. This additional 
income is mostly used by poor families to buy the family needs. In addition, waste saving is also used for the purposes of financing the needs of their children which include meals for schools, buying children's school supplies and also the transportation costs. Sometimes waste savings are also used by poor families in Sicanang Belawan for the cost of renting boats or cost of repairing their boats.2. Besides the advantages economically, waste saving also provides some advantages socially which are marked by a change in people's behavior in managing the waste that includes; behavior in sorting waste and increasing participation in waste management. In addition, the people of Sicanang Belawan also have increased skills in recycling inorganic waste that affects the increased income from the sale of recycling waste products.

\section{Books:}

\section{REFERENCES}

[1] BPS Kota Medan.2009, 2010, 2011, 2012.Medan Dalam Angka. Medan: BPS Kota Medan.

[2] Idrus, Muhammad.(2009). Metode Penelitian Ilmu Sosial; Pendekatan Kualitatif dan Kuantitatif. (Edisi Kedua). Jakarta: Penerbit Erlangga.

[3] Kaelan, M.S, Prof.,DR.. 2012. Metode Penelitian Kualitatif Interdisipliner bidang Sosial, Budaya, Filsafat, Seni, Agama dan Humaniora. Yogyakarta: Penerbit Paradigma.

[4] Soelaeman, M. Munandar. 2011. Ilmu Sosial Dasar; Teori dan Konsep Ilmu Sosial. Bandung: Reflika Aditama.

[5] Stamboel, Kemal A. 2012. Panggilan Keberpihakan: Strategi Mengakhiri Kemiskinan di Indonesia. Jakarta: PT Gramedia Pustak aUtama.

[6] Sugiyono. (2010). Metode Penelitian Kuantitatif, Kualitatif dan R\&D. Bandung: Penerbit Alfabeta.

[7] Suwerda, Bambang.2012. Bank Sampah; KajianTeoridanPenerapan). Yogyakarta: Pustaka Rihama.

[8] Suyanto, Bagong. 2013. Anatomi Kemiskinan dan Strategi Penanganannya: Fakta Kemiskinan Masyarakat Pesisir, Kepualauan, Perkotaan dan Dampak dari Pembangunan di Indonesia. Malang: InTRANS Publishing.

[9] Utami, Eka. 2013. Buku Panduan Sistem Bank Sampah\& 10 Kisah Sukses. Jakarta: Yayasan Unilever Indonesia. Journal and Thesis:

[10] Augus, Efendi dan Mujahiddin. 2016. Model Pengelolaan Sampah Anorganik di SMP N 8 Medan dan SMP N 3 Medan. KESKAP: Jurnal Ilmu-Ilmu Sosial FISIP UMSU. Vol. 14, No. 01, Rabiul Awal 1437 $\mathrm{H} / \mathrm{Januari} 2016 \mathrm{M}$.

[11] Candra, Ibrahim. 2012. Partisipasi Masyarakat Dalam Pengelolaan Sampah Rumah Tangga; Study Kasus Di Kelurahan Siantan Tengah Pontianak Utara.Sociodev, Jurnal S-1 IlmuSosiatri. Vol. 01 No. 01 Edisi Perdana 2012.Hal. 1-21. Pontianak: UniversitasTanjungpura.

[12] Simangungsong, Rahidun.2003. Analisis Partisipasi Masyarakat Terhadap Program Kebersihan Sampah Di Kota Pematang Siantar.Tesis. Medan: Program PascaSarjana Universitas Sumatera Utara.

[13] Syafrini, Delmira. 2013. Bank Sampah: Mekanisme Pendorong Perubahan Dalam Kehidupan Masyarakat, Studi Kasus; Bank Sampah Barokah Assalam Perumahan Dangau Teduh Kecamatan Lubuk Begalung, Padang. Jurnal Humanus. Vol. XII. No. 2 Thn 2013.Act:

[14] Undang-Undang Republik Indonesia No. 18 Tahun 2008: Tentang Pengelolaan Sampah.

[15] Undang-Undang Republik Indonesia No. 52 Tahun 2009: Tentang Perkembangan Kependudukan dan Pembangunan Keluarga. 